\title{
Emotional trauma as a fearful fact among rural women of Haryana
}

\author{
GAITRI, MANJU DAHIYA AND KUSUM RANA* \\ Department of Extension Education and Communication Management, I.C. College of Home Sciences, \\ C.C.S. Haryana Agricultural University, HISAR (HARYANA) INDIA
}

\begin{abstract}
According to a recent G20 survey, India is the worst place to be a woman. Female foeticide, domestic violence, sexual harassment, and other forms of gender-based violence constitute the reality of most girls' and women's lives in India. In a typical Haryana family, violence is central to the discipline required for maintaining the rule of authority and male is the undisputed head of the family. Besides bearing a disproportionate burden of household work, women from Haryana suffer the most from domestic violence. Emotional abuse further aggravates the situation. Emotional abuse is a kind of abuse that may include anything from verbal abuse and constant criticism to more subtle tactics, such as intimidation, manipulation and refusal to ever be pleased due to which the victim may experience severe psychological trauma. This may involve the tactics of brain washing that may constitute psychological abuse as well but emotional abuse principally consists of the manipulation of the victim's emotions. The victims' emotions are controlled by the abuser to a point where they lose any feeling for themselves. Their self-esteem and independence are 'systematically taken away' from them. It is estimated that 14 per cent of Indian women have experienced emotional abuse at some point in their lives. All sorts of violence against women are on increase as is clear from the statistics of some parts of Haryana. The Women and Child Welfare Society Haryana (WCWSH) reported 3,500 cases of domestic violence registered with Women Cells in 2009, with a sharp rise in the number of cases in a span of five months (April-August, 2010) to 2181. Out of these, most of the cases (292) of domestic violence were from Hisar district, 94 were from Kaithal and 16 from Panchkula. Keeping in view an abysmally large number of cases of violence against women in Haryana, a study was planned to have a preliminary assessment of prevalence of domestic violence against women in the Hisar district of Haryana. Sixty respondents, who had encountered domestic violence in one form or the other, regularly visited Protection Officer and could be telephonically contacted easily were purposively selected for the study from Hisar and nearby villages. The respondents were personally interviewed at the office of Protection Officer, Hisar in 3-4 meetings with each respondent. Majority of the respondents comprised the age group of 20-30 years, belonged to weaker socioeconomic strata and had a low family education status. Five per cent of the respondents faced first violence within 13 years of marriage followed by those during $2-5$ years $(10 \%)$ and 5 years after the marriage $(11.67 \%)$. Data clearly reflected that in 91.67 per cent of the cases domestic violence was perpetrated by husband, followed by those involving mother-in-law (66.67\%). Respondents faced a variety of domestic violence after marriage; emotional (100\%), verbal (96.66\%) and physical (95.10\%), whereas majority of the respondents complained of cases pertaining to violence on economical/financial ground $(88.33 \%)$ and sexual ground $(58.33 \%)$. Data pertaining to nature of emotional violence revealed that among the different types of emotional violence, cent per cent respondents faced wife battering (silent crime), followed by those who faced accusation on character and denial of basic facilities ( $90 \%$ ), constant criticism (89 $\%$ ), ignorance (86.67\%), denied help when injured/sick (85\%), insult for not bringing dowry and denial to meet any
\end{abstract}

\footnotetext{
* Author for correspondence

Directorate of Extension Education, C.C.S. Haryana Agricultural University, HISAR (HARYANA) INDIA
} 